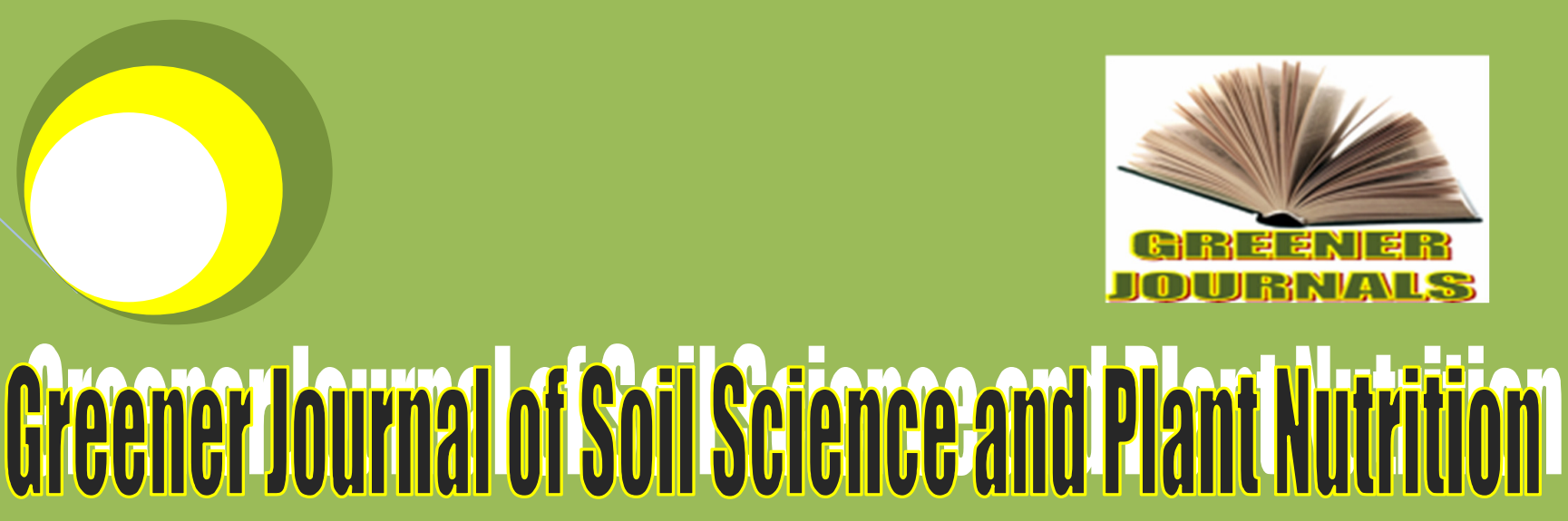

ISSN: 2384-6348

Submitted: $12 / 07 / 2017$

Accepted: 14/07/2017

Published: 30/07/2017

DOI: http://doi.org/10.15580/GJSSPN.2017.2.071217081

Effect of Soil Nutrient

Status on Carcass

Quality of Pond-

Raised Tilapia,

Oreochromis niloticus

(Linnaeus, 1758)

By

Chikere-Njoku C.

Njoku D.C. 


\title{
Research Article (DOI: http://doi.org/10.15580/GJSSPN.2017.2.071217081) \\ Effect of Soil Nutrient Status on Carcass Quality of Pond-Raised Tilapia, Oreochromis niloticus (Linnaeus, 1758)
}

\author{
Chikere-Njoku C. ${ }^{1}$ and Njoku D.C. ${ }^{2}$ * \\ ${ }^{1}$ Department of Soil Science and Environment, Imo State University Owerri \\ ${ }^{2}$ Department of Fisheries and Aquaculture, Federal University of Technology Owerri. \\ *Corresponding Author's E-mail: dajokks@ yahoo. com; Tel: +(234) 8036742857
}

\begin{abstract}
The effect of nutrient status of soil on carcass quality of fish raised in earthen ponds was investigated between March and August 2016. Three soil profile pits were dug side by side three existing earthen ponds in three different geomorphological locations of Imo State at Umuagwo, Ulakwo and Uboma. Three homogenous soil horizons ( 0-20, 20-60, $60-150 \mathrm{~cm}$ ) were identified and evaluated for nutrient composition by standard methods (USDA, 1971). Ten adults of Oreochromisniloticus of average weight of $250.0 \pm 5.4 \mathrm{~g}$ randomly selected from the associated earthen ponds were chemically evaluated for carcass composition in accordance with AOAC (2005). Soil textural class for the pond at Umuagwo was dominantly sandy, sandy loam at Ulakwo and clay loam at Uboma. Soil nutrient analysis showed that the sandy soil was grossly poor in total nitrogen $(0.04-0.08)$ and soil exchangeable bases, $\mathrm{K}(0.01$ $0.04 \%), \mathrm{Na}(0.003-0.005 \%)$ as against the clay soil which had appreciably higher reserve of total nitrogen $(0.21-0.32 \%)$, organic carbon (1.22-2.50\%) and exchangeable bases, $\mathrm{K}(0.06-0.18 \%)$, and $\mathrm{Na}(0.020 .09 \%)$. Nutrient composition of fish carcass from the clay pond in terms of two most important nutritive factors of crude protein $(32.1 \pm 3.0 \%)$ and fat $(6.36 \pm 0.1 \%)$ was significantly higher $(P<0.05)$ than in the sandy pond $(14.7 \pm 2.0 \%), 4.4 . \pm 0.5 \%)$ and the sandy loam $(14.9 \pm 25 \%, 4.7 \pm 0.2 \%)$ respectively. The implication of this in site selection of earthen ponds is discussed.
\end{abstract}

Key words: Soil nutrient, carcass quality, Oreochromisniloticus.

\section{INTRODUCTION}

The value of any food product, including fish is a function of it's nutritive properties, evaluated in terms of health promoting factors such as crude protein content, lipid, vitamins, minerals and other valuable substances present (Novikov, 1983, Njoku, 2015). The awareness of the unique nature of fish nutrients in human diets and health management has tremendously increased in recent times, resulting in an unprecedented demand for fish in preference to other sources of animal protein. Fish is now a dietary delicacy and preferred menu in households and all important occasions as well as for patients on special diets.

It is speculated (Njoku, 2004) that the quality of dietary nutrient in pond-raised fish may be related to the nutrient status of the environment in which the fish was cultured, including the water and the underlying soil conditions. Consequently the study seeks to investigate the effect of soil nutrients status on carcass quality of Oreochromisniloticus raised in earthen ponds in Imo state. It is believed that the study will contribute to innovations in modeling the aquatic ecosystem and the design of modern aquatic productive systems. Quantification of proximate composition of fish carcass is also a requirement in aquatic food regulation and commercial specifications in global trade (Waterman, 2000).

\section{MATERIALS AND METHOD}

\section{A. SELECTION OF FISH PONDS AND EXPERIEMENTAL DESIGN}

Three existing earthen fish ponds were selected for the trial at Umuagwo in Ohaji-Egbema LGA, Ulakwo in NgorOkpala LGA and Uboma in Ihitte-Uboma LGA of Imo state. Each pond measured approximately $30 \mathrm{~m} \times 25 \mathrm{~m}$ $\times 1.5 \mathrm{~m}\left(750 \mathrm{~m}^{2}\right)$ and stocked with 7,500 fingerlings of tilapia (Oreochromisniloticus) of mean body weight of $15.0 \pm$ 0.8 grams at the rate of 10 fingerlings $/ \mathrm{m}^{2}$. The fish were fed with commercial feed concentrates at $5 \%$ body weight divided into two feeding regimes of mornings (0600 hours) and evenings (18000 hours) and six days in the week. The trial was designed as a completely randomized experiment (CRD) with three replications. The mathematical model (Njokuet al. 1998) is as follows: 


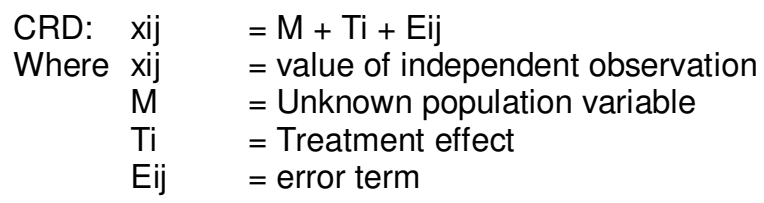

\section{B. SOIL PROFILE PIT SELECTION AND SOIL CHEMICAL (NUTRIENT) ANALYSIS}

In each of the pond locations at Umuagwo, Ulakwo and Uboma, a soil profile pit was dug. Each pit measured $1 \mathrm{~m}$ $\times 1 \mathrm{~m} \times 1.5 \mathrm{~m}$ deep. The depth was chosen in line with the maximum permissible depth of fish ponds as 1.5 meters (Njoku, 2000). The colour of the various soil horizons in the soil profile was qualitatively determined on exposure by visual method and by use of colour chart (FAO, 1977). Thereafter soil samples were collected in triplicates from each of the homogenous horizons for separate analysis.

\section{LABORATORY ANALYSIS}

\section{(i) Soil moisture}

Moisture content of the soil was estimated by gravimetric method (Singer \& Mum, 1996). Known weight of the soil sample was collected in Petri dish, dried to constant weight in an oven at a temperature of $105^{\circ} \mathrm{C}$ and reweighed. Moisture content (\%)was computed thus:

$$
\begin{aligned}
& \text { Soil moisture content }(\%)=\left(\begin{array}{lll}
\frac{W b-W c}{W b-W a} & \times \frac{100}{1}
\end{array}\right) \\
& \text { Where } \quad \begin{array}{ll}
W a \quad=\text { Weight of empty dish } \\
W b \quad=\text { Weight of dish + wet sample before oven drying } \\
W c \quad=\text { Weight of dish + dried sample. }
\end{array}
\end{aligned}
$$

\section{ii. Soil particle size analysis and textural class determination}

Standard method was adopted in soil particle size analysis using sodium hexametaphosphate as dispersant after treating the sample with hydrogen peroxide to remove the organic matter (Singer \& Mum, 1996, Barnabas \&Nwaka 2014). Thereafter the soil textural classes were determined using the soil textural triangle.

\section{iii. Soil Chemical (Nutrient) analysis}

Soil chemical analysis was carried out in accordance with standard analytical methods by USDA (1971), Udoh\&Lekwa (2014). Organic carbon was determined by the acid dichromate digestion method, total nitrogen by micro Kjeldahl digestion and ammonia distillation method. Exchangeable bases (saturated extract) of calcium (Ca) and Magnesium, (Mg) by the EDTA titrimetric method (Cheng and Bray, 1951) and atomic absorption spectrophotometer, while sodium ( $\mathrm{Na}$ ) and Potassium (K) were extracted using the flame photometric method. Total phosphorus $(P)$ was by perchloric acid digestion method (Jackson, 1956). Cation exchange capacity (CEC) was estimated by the centrifugation method using ammonium acetate $\left(\mathrm{NH}_{4} \mathrm{OAc}, \mathrm{PH}\right.$ 7.0), Sodium acetate ( $\mathrm{NaOAc}, \mathrm{pH} 8.2$ ) and potassium acetate (KOAc, $\mathrm{pH}$ 7.0). Base saturation (B.S) were then estimated by dividing the sum of the extracted bases by the base exchange capacity.

\section{Proximate Composition Analysis of Fish Carcass}

After six months of culture, 10 adult fish, with average weight of $250.0 \pm 5.4 \mathrm{~g}$ were randomly selected from each of the earthen ponds at Umuagwo, Ulakwo and Uboma and processed for carcass analysis at the Fisheries Wet Laboratory, Federal University of Technology Owerri. Samples were analyzed chemically in accordance with the methods of Official Analytical chemists (AOAC, 2005). Nutrients evaluated include crude protein, crude fat, ash, fibre, moisture, free nitrogen extract (NFE) and caloric value.

Moisture content was determined using the oven dry method, ash by muffle furnace method, crude fibre by the reflux method, crude fat by the soxhlet extraction technique and crude protein by the micro Kjeldahl apparatus. The various parameters were estimated as follows:

$$
\text { i. Carcass Moistures content }(\%)=\frac{W b-W c}{W b-W a} \times \frac{100}{1}
$$




\section{Where}

$\mathrm{Wa}=$ Weight of weighting bottle only

$\mathrm{Wb}=$ Weight of weighing bottle + sample before drying

Wc $=$ Weight of weighing bottle + sample after drying

ii. Ash content $(\%)=\frac{W c-W a}{W b-W a} \quad \frac{X 100}{1}$

Where

$\begin{array}{lll}\mathrm{Wa} & = & \text { Weight of empty crucible } \\ \mathrm{Wb} & = & \text { Weight of Crucible }+ \text { sample before ashing } \\ \mathrm{Wc} & = & \text { Weight of crucible }+ \text { sample after ashing }\end{array}$

iii. Crude fibre $(\%)=\underset{\text { Weight of original sample }}{\frac{W_{2}-W_{1}}{1}} \frac{100}{1}$

Where $W_{1}=$ Weight of empty crucible

$\mathrm{W}_{2}=$ Weight of crucible and it's contents after incineration

iv. Crude fat (\%) $=\frac{W_{2}-W_{1}}{\text { Weight of original sample }} \underset{\frac{100}{1}}{ }$

Where $W_{1} \quad=$ Weight of empty beaker only

$W_{2}=$ Weight of beaker + ether extract.

\section{v. Crude protein}

The crude protein was obtained by multiplying the \% Nitrogen content by a constant factor of 6.25 , where the $\%$ Nitrogen is estimated thus:

$\% \mathrm{~N}=(\mathrm{T}-\mathrm{B}) \times \frac{\text { Normility } \mathrm{X} \text { atomic mass } \times \text { vol } \times 100}{\text { Weight of original sample }}$

Where $\quad \mathrm{T}=$ Titre value of sample

$\mathrm{N}=\quad$ Normality of $\mathrm{Hcl}$ used

Atomic $=\quad$ Factor for atomic mass of Nitrogen

$\mathrm{Vol}=$ volume of digest

vi. Nitrogen free extract (NFE) was determined by subtracting the sum of $(\%$ moisture $+\%$ C.P $+\%$ crude fat $+\%$ crude fibre $+\%$ ash) from 100 .

NFE (\%) $\quad=100-(\% M+\%$ C.P $+\%$ C.F $+\%$ ash $+\% E E)$

\section{vii. Caloric Value (Energy)}

The caloric value (Kcal) was obtained by multiplying the value of the C.P, EE and NFE by 4,9 and 4 respectively as the sum of the product.

i.e Caloric value $(\mathrm{Kcal} / 100 \mathrm{~g})=(\mathrm{C} . \mathrm{P} \times 4)+\mathrm{EE} \times 9)+(\mathrm{CHO}$ or NFE $\times 4)$

\section{STATISTICAL METHOD}

Data resulting from the completely randomized trial (CRD) was analyzed with one way analysis of variance (ANOVA) as described by Steel and Torrie (1980), and Njokuet al (1998). Significant differences in mean values of parameters were separated using the Duncan's Multiple Range test (Duncan, 1955). This statistical analysis employed the Computer Statistical Package for Social Science (SPSS), version 19, window 8. 


\section{RESULTS}

\section{SOIL TEXTURAL PROPERTY}

Tables $1-3$ show the particle size distribution of the soil profiles developed at Umuagwo (recent alluvium), Ulakwo (coasted plain sands) and Uboma (sand stone and marine shale) respectively. The result shows that while the soil at Umuagwo (table 1) is dominantly sandy, (sand: $94.4-95 \%$, silt: $0.4-0.6 \%$ and clay $4.9-5.2 \%$ ) in two out of 3 soil horizons, the soil at Ulakwo (table 2) was dominantly sandy loam (sand: $60.5-65.0 \%$, Silt: 15.5$18.0 \%$ and clay: $19.5-21.5 \%$ ) in two out of the three soil horizons. The soil at Uboma (table 3 ) was dominantly clay loam in two of the three horizons (sand: $25.5-47.8 \%$, silt: $24-26.5 \%$, clay: $28.8-45.0 \%$ ). The third horizon was clay (sand fraction: $22.0 \%$, silt: $14.0 \%$ and clay: $64.0 \%$ ).

Table 1: Particle size distribution of soil profile developed at Umuagwo, Imo State (recent alluvium)

\begin{tabular}{|l|lll|l|}
\hline \multicolumn{5}{|c|}{ Soil Particle size \% } \\
\hline Soil depth $(\mathrm{Cm})$ & Sand & Silt & Clay & Soil texture \\
\hline $0-20$ & 95.0 & 0.6 & 4.9 & Sandy \\
$20-60$ & 94. & 0.4 & 5.2 & Sandy \\
$60-150$ & 50.0 & 34.0 & 20.0 & Sandy Loam \\
\hline
\end{tabular}

Table 2: Particle size distribution of soil profile developed at Ulakwo Imo state (coastal plain sands)

\begin{tabular}{||l|lcl|l|}
\multicolumn{5}{|c|}{ (coastal plain sands) } \\
\hline Soil depth $(\mathrm{Cm})$ & Sand & Salt & Clay & Soil texture \\
$0-20$ & 80.7 & 14.5 & 4.8 & Sandy \\
$20-60$ & 65.0 & 15.5 & 19.5 & Sandy Loam \\
$60-150$ & 60.5 & 18.0 & 21.5 & Sandy Loam \\
\hline \multicolumn{5}{|c|}{} \\
\hline
\end{tabular}

Table 3: Particle size distribution of soil profile developed of Uboma, Imo State (sand stone and marine shales)

\begin{tabular}{|l|lcc|l|}
\hline \multicolumn{5}{c|}{ Soil particle size (\%) } \\
\hline Soil depth $(\mathrm{Cm})$ & Sand & Silt & Clay & Soil texture \\
$0-20$ & 47.8 & 24.0 & 28.8 & Clay Loam \\
$20-60$ & 28.5. & 26.5 & 45.0 & Clay loam \\
$60-150$ & 22.0 & 14.0 & 64.0 & Clay \\
\hline
\end{tabular}

\section{SOIL NUTRIENT (CHEMICAL) COMPOSITION}

Tables 4-6 summarize the nutrient status of the three different geomorphological soils at Umuagwo, Ulakwo and uboma.

The result (table 4) shows that the sandy soil at Umuagwo is strongly acidic with $\mathrm{pH}$ ranging from 4.04.5). The organic carbon content (C.O) was low $(0.4-0.6 \%)$ as well as total nitrogen $(0.04-0.08 \%)$. The soil is generally poor, especially in exchangeable bases ( $\mathrm{Ca}, \mathrm{Mg}, \mathrm{K}$ and $\mathrm{Na}$ ).

Table 5 shows the nutrient profile of the coastal plain soil at Ulakwo. The soil is also strongly acidic, though organic carbon content was medium. Ttotal nitrogen $(0.06-0.08 \%)$ and potassium $(0.04-0.06 \mathrm{Me} / 100 \mathrm{~g})$ were also low. Exchangeable $\mathrm{Ca}, \mathrm{Mg}$ and $\mathrm{Na}$ were also low. For the soil at Uboma (table 6), the soil was also strongly acidic $(4.5-5.0)$ but medium in organic carbon $(0.22-0.50 \%)$. It was also reasonably high in total nitrogen $(0.21-0.32 \%)$ and exchangeable bases, $\mathrm{K}(0.06-0.18 \mathrm{me} / 100 \mathrm{~g})$. In all the three soil types, base saturation (B.S) and the exchangeable cation exchange capacity (CEC) were generally high and same.

Table 4: Chemical analysis of the recent alluvial soil from soil profile developed at Umuagwo, Imo state

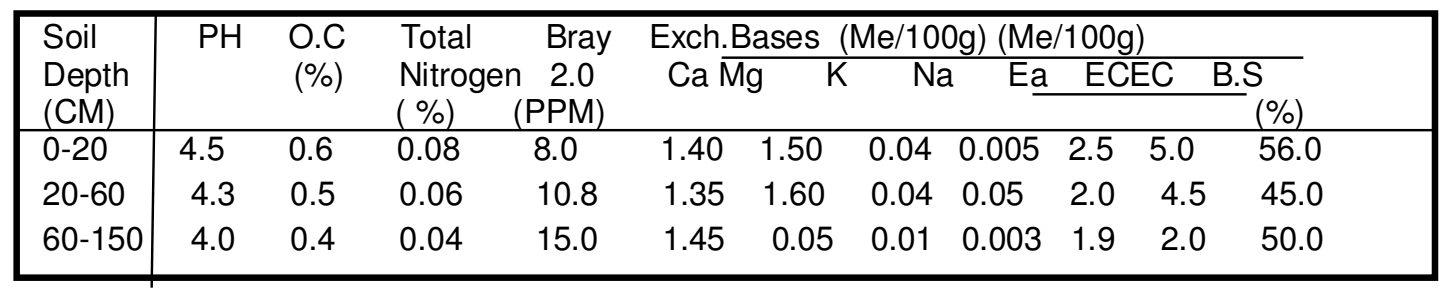


$\mathrm{OC}=$ organic carbon

Table 5: Chemical analysis of the coastal plain soils from the soil profile developed at Ulakwo, Imo state

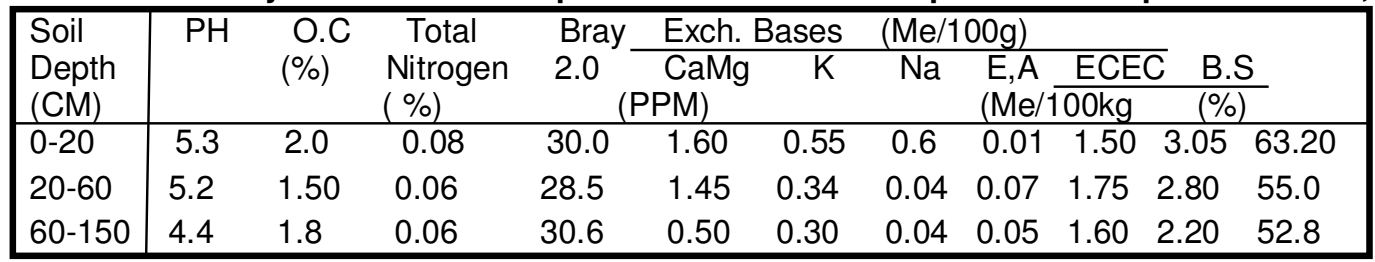

Table 6: Chemical analysis of the soils formed from marine sand stones and shells from the soil profile developed at Uboma, Imo state

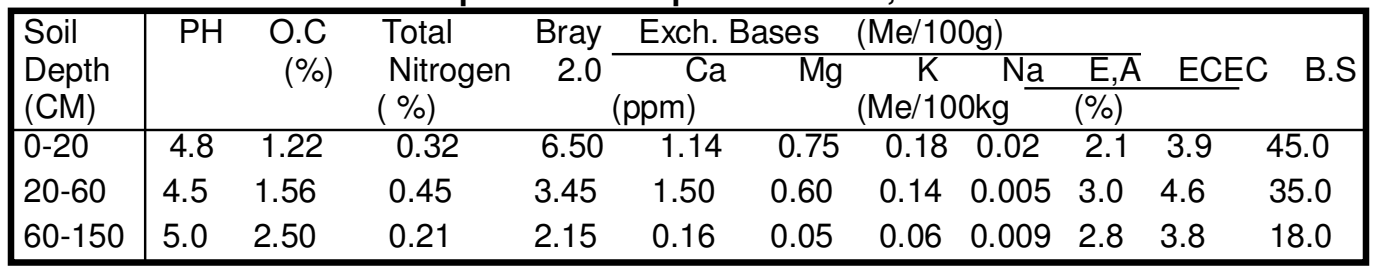

\section{NUTRIENT COMPOSITIONS OF FISH CARCASS}

Tables 7-9 present the proximate composition of fish carcass from the three different geomorphological soils of Imo state. Crude protein and fat were $(14.2 \pm 0.8 \%$ and $12.3 \pm 1.2 \%)$, for the fish from sandy pond (Fig 7$)$, ( $18.1 \pm 1.0 \%$ and $11.1 \pm 0.2 \%)$ for the sandy loam (Table 8$)$ and $(27.6 \pm 2.0 \%$ and $18.2 \pm 0.8 \%)$ for fish from the clay loam ponds (Table 9). Mean value of the nutrients varied between the three geomorphological fish ponds. Mean moisture content $(85.5 \pm 4.0 \%, 76.10 \pm 4.5 \%$ and $69.2 \pm 5.5 \%)$ respectively for the sandy,. Sandy loam and clay loam ponds as well as the caloric value $(157.7 \pm 5.8 \overline{\mathrm{Kcal}} / 100 \mathrm{~g}, 194.3 \pm 6.5 \mathrm{Kcal} / 100 \mathrm{~g}$ and $362 \pm 8.5$ $\mathrm{Kcal} / 100 \mathrm{~g}$ also varied in fish from the different ponds. In all the parameters, the fish reared in clay soils were appreciably higher in nutrients than others. It was also observed that as fat content of the fish carcass increased, the caloric value also increased while moisture content reduced in all the specimens.

Table 7: Carcass composition of pond-raised Tilapia (O. niloticus) in sandy soil at Umuagwo (resent alluvium)

\begin{tabular}{|l|lllllll|}
\hline & \multicolumn{7}{|c|}{ Nutrient Composition (\%) } \\
\hline Sample & C.P & Lipid & Fibre & Ash & Moisture & NFE & $\begin{array}{l}\text { Caloric value } \\
\text { (Kcal/100g }\end{array}$ \\
& $(\mathrm{N} \times 6.25)$ & & & & & & 82.5 \\
1 & 15.0 & 13.0 & 0.85 & 85.0 & 86.5 & 6.50 & 80.3 \\
2 & 12.8 & 10.5 & 0.80 & 80.5 & 84.8 & 5.50 & 8.00 \\
3. & 14.8 & 12.5 & 0.80 & 85.0 & 80.0 & 6.00 & 85.0 \\
\hline Mean $\overline{\left(\mathrm{X}_{ \pm} \mathrm{SE}\right)}$ & 14.2 & 12.3 & 0.77 & 0.70 & 83.5 & 6.00 & 82.60 \\
& \pm 0.8 & \pm 1.2 & \pm 0.02 & \pm 0.03 & \pm 5.05 & \pm 0.15 & \pm 5.5 \\
\hline
\end{tabular}

Note: 1 kilocalorie $(\mathrm{Kcal})=$ the quantity of heat required to charge the temperature of 1 litre of water by $1^{\circ} \mathrm{C}$.

Table 8: Carcass composition of pond-raise Tilapia. (0. niloticus) in sandy loam soil at Ulakwo (coastal plain sand)

\begin{tabular}{|l|ccccccc|}
\hline \multirow{2}{*}{ Sample } & C.P & Lipid & Fibre & Ash & Moisture & NFE & Caloric value \\
& & & & & & & (Kcal/100g \\
\hline 1 & 18.5 & 12.5 & 0.75 & 0.60 & 75.8 & 4.5 & 158.0 \\
2 & 17.6 & 10.8 & 0.75 & 0.55 & 80.5 & 5.0 & 250.0 \\
3. & 18.0 & 11.0 & 0.80 & 0.50 & 72.0 & 5.5 & 195.0 \\
\hline Mean $\overline{\left(X_{ \pm} \text {SE) }\right.}$ & 18.1 & 11.1 & 0.77 & 0.55 & 76.10 & 5.0 & 194.3 \\
& \pm 1.0 & \pm 0.2 & \pm 0.05 & \pm 0.04 & \pm 4.5 & \pm 0.5 & \pm 6.5 \\
\hline
\end{tabular}


Table 9: Carcass composition of pond raised tilapia (0.niloticus) in Clay soils at Uboma (sand stone and marine shale)

\begin{tabular}{|l|ccccccc|}
\hline \multirow{2}{*}{ Sample } & \multirow{7}{*}{ C.P } & Lipid & Fibre & Ash & Moisture & NFE & Caloric value \\
& & & & & & & (Kcal/100g \\
\hline 1 & 26.8 & 16.0 & 0.65 & 0.56 & 70.5 & 5.0 & 365.0 \\
2 & 28.5 & 18.5 & 0.70 & 0.65 & 72.0 & 4.6 & 378.0 \\
3. & 27.5 & 20.0 & 0.75 & 0.60 & 65.0 & 4.5 & 345.0 \\
\hline Mean $\left(\bar{X}_{ \pm}\right.$SE) & 27.6 & 18.2 & 0.70 & 0.60 & 69.2 & 4.7 & $362 \pm 8.5$ \\
& \pm 2.0 & \pm 0.6 & \pm 0.03 & \pm 0.05 & \pm 5.5 & \pm 0.5 & \\
\hline
\end{tabular}

\section{COMPARISON OF THE PROXIMATE COMPOSITION OF FISH CARCASS FROM EARTHEN PONDS OF DIFFERENT SOIL TEXTURAL PROPERTY}

Nutrient composition of Clariasgariepinus raised in soils of different textural classes was compared in table 10. The result showed that whereas fish nutrients varied between the three different ponds, crude protein ( $27.6 \pm$ $2.0 \%$ ), crude fat $(18.2 \pm 2.0 \%$ and the caloric value $(362.0 \pm 8.5 \mathrm{Kcal} / 100 \mathrm{~g})$ observed in the tissue of fish raised in the clay soil were significantly higher $(P<0.05)$ than those of other ponds.

\section{DISCUSSION}

The result shows that soils rich in clay have good reserves of total nitrogen and available phosphorus compared to sandy and sandy loam soils. This may be attributed to the differences in their parent materials. According to Ohiri and Ano (1992), sandy soils have multi nutritional problems due to the quartz sand as the parent material while clay loam soils with sandstones and marine shales as parent materials are usually high in available phosphorus, total nitrogen and potassium. Novikov (1983) explains that aquatic plants and animals need nitrogen compound in the form of nitrate ions $\left(\mathrm{NO}_{3}^{-}\right)$and ammonium ion $\left(\mathrm{NH}_{4}+\right.$ ) to form protein and other important molecules like DNA and Vitamins in the body tissue. Mineral compounds of phosphorus $(P)$ extracted from the underlying soil occur in water (fish pond) as orthophosphate $\left(\mathrm{PO}^{3-}{ }_{4}\right)$ ions and utilized by aquatic plants (algae and fungi) and considered as a limiting factor for primary production and fish yield in ponds (De Vere, 1996). Those polyphosphates and nitrogenous compounds derived from soil phosphorus and total nitrogen undergo series of continuous conversions in aquatic ecosystem to form nucleotides (nucleic acid) which are present in living cells of fish as deoxyribonucleic acid (DNA) and ribonucleic acid (RNA) (Njoku 2014). Nitrogen found in soil, through the process of nitrification (nitrogen fixation) is converted to mineral (organic) compounds of nitrogen by aquatic plants (blue-green algae and some fungi). They occur in water as ions of ammonia $\left(\mathrm{NH}_{4}^{+}\right)$, and nitrate $\left(\mathrm{NH}_{3}{ }^{-}\right)$. Green plants take up the inorganic forms of Nitrogen $\left(\mathrm{NH}_{3}\right.$ and $\left.\mathrm{NO}_{3}\right)$ during assimilation and reduce them to ammonia and finally to aspartic and glutamic acids as precursors in protein formation in fish. The foregoing seem to explain the positive relationship which exists between soils of high inorganic nutrient (total nitrogen, available phosphorus and exchangeable bases), and nutrient status of fish carcass from the difference earthen ponds. Another pertinent observation is that as the fat content of the fish increased, the moisture content declined. This is in agreement with the observations of Novikov (1983) that the greater the quantity of fat in fish flesh, the smaller the quantity of water and vice versa. Similarly, it was observed that the higher the lipid (fat) content of the fish the higher the caloric value of the fish. Novikov (1983) is of the view that fish fat which is rich in phosphorus, particularly adenosine tri-phosphate has high energy equivalents than other nutrient parameters in fish, adding that in the course of assimilation, 1gram of protein releases 4.1 calories of heat, carbohydrate 4.1 and fat as much as 9.3 calories per gram. 
Table 10: comparison of proximate composition of fish carcass raised in earthen ponds with soils of different textural properties

\begin{tabular}{|c|c|c|c|c|c|c|c|}
\hline \multirow[b]{2}{*}{$\begin{array}{l}\text { Soil/Pond } \\
\text { Location }\end{array}$} & \multicolumn{7}{|c|}{ Nutrient Parameter of fish $(\mathrm{X} \pm \mathrm{SE})$} \\
\hline & $\begin{array}{l}\text { C.P } \\
\text { (\%) }\end{array}$ & $\begin{array}{l}\text { FAT } \\
(\%)\end{array}$ & $\begin{array}{l}\text { Ash } \\
(\%)\end{array}$ & $\begin{array}{r}\text { Moisture } \\
(\%) \\
\end{array}$ & $\begin{array}{c}\text { Fibre NFE } \\
(\%) \\
\end{array}$ & $\begin{array}{l}\text { Caloric Value } \\
(\%)\end{array}$ & $(\mathrm{Kcal} / 100 \mathrm{~g})$ \\
\hline $\begin{array}{l}\text { Umuagwo } \\
\text { (Sandy soil) }\end{array}$ & $14.72 \pm 0.8^{a}$ & $12.3 \pm 1.2^{\mathrm{a}}$ & $0.77 \pm 0.02^{a}$ & $83.5 \pm 4.0^{a}$ & $0.81 \pm 0.01^{a}$ & $4.9 \pm 0.1^{a}$ & $181.7 \pm 5.8^{a}$ \\
\hline $\begin{array}{l}\text { Ulakwo } \\
\text { (Sandy loam) }\end{array}$ & $18.1 \pm 1.0^{b}$ & $11.1 \pm 0.2^{a}$ & $0.55 \pm 0.04^{b}$ & $76.10 \pm 4.5^{b}$ & $0.77 \pm 0.05^{a}$ & $5.0 \pm 0.5^{a}$ & $194.3 \pm 6.5^{\mathrm{a}}$ \\
\hline $\begin{array}{l}\text { Uboma } \\
\text { (Clay Loam-Clay) }\end{array}$ & $27.6 \pm 2.0^{c}$ & $18.2 \pm 0.8^{b}$ & $0.60 \pm 0.03$ & $60.2 \pm 5.5^{\mathrm{bc}}$ & $0.70 \pm 0.03^{b}$ & $4.7 \pm 0.5^{a}$ & $363 \pm 8.5^{c}$ \\
\hline
\end{tabular}

abc: mean values in the same column with different super scripts are significantly different at $F=0.05$ $\mathrm{SE}=$ Standard Erro 


\section{CONCLUSION}

It would seem that clay soil, which is rich in inorganic nutrients is positively related to the dietary quality of cultured Oreochromisniloticus in earthen ponds. This is an important consideration in site selection of fish ponds.

\section{REFERENCES}

AOAC (2005) Official methods of Analysis of the Association of Official Analytical Chemists (18 ${ }^{\text {th }}$ ed), Mary land, USA, $1550 \mathrm{pp}$.

USDA (1971) Soil survey laboratory methods and procedure for collecting soil samples. Soil Conservation Service, US Department of Agriculture (soil survey investigations report No 1) Washington D.C, USA 63 pp.

Asadu, C.L.A: Chibuike, G.U, Dixon, A.G.O (2014) micronutrients availability in a cleared forest land after seven years of continuous cultivation and eight years of natural fallow in an Alfisol in Eastern Nigeria: In S.O. Ojeniyiet al (eds). Nigerian Agricultural Transformation Agenda, Soil as a key to National development, pp $317-324$, Proceedings of the $38^{\text {th }}$ Annual conf of Soil Science Society of Nigeria, Univ of Uyo, Nigeria, March $10-14,2014$.

Barnabas, I. M and G.I.C. Nwaka (2014) Characterization of upland soils of Jiwa in the Federal Capital Territory, Abuja, In: S.O. Ojeniyiet al (eds). Nigerian Agricultural Transformation Agenda, Soil as a key to National Development, pp 106-113. Proceedings of the 38 ${ }^{\text {th }}$ Annual conf of Soil Science Soc. Nigeria.Univ of Uyo, Nigeria, March 10-14, 2015.

Cheng, K. L and R. H. Bray (1951) Determination of calcium and magnesium in soil and plant materials, Soil sc. 72 : 449-458.

Devere B. (1966) Ecology of fish and wildlife.Delmer Thomson Learning inc. New York, United States of America. $420 \mathrm{pp}$.

Duncan, D.B (1955) Multiple range and multiple F test. Biometrics 11: 1-42.

FAO (1977) Guidelines for soil profile description. Soil survey and fertility branch land and water Dev. Div, Food and Agriculture Organization (FAO), Rome. Italy. 560 pp.

Jackson, M.L (1956) Soil chemical analysis, advanced course. Prentice Hall Inc. Madison, USA, 991 pp.

Njoku, D.C (2014) Fish Biology and Taxonomy.Brighton Graphic Publishers, Owerri, Nigeria 250 pp.

Njoku, D.C (2004) The Ecology of Nigerian Fishes, An introductory course.Contacom communications Ltd, Owerri, Imo State Nigeria, $53 \mathrm{pp}$.

Njoku D.C ; M.O. Onuh and N.C Ohazurike (1998). Research methods and field Experimentation in Agriculture and Biological Sciences. Alphabet Nigeria publishers Ltd. Owerri, Nigeria. 111pp

Novikov, V.M (1983) Hand book of Fishery Technology (vol.1) PishechevayaPromychlennost Publishers, Moscow. $491 \mathrm{pp}$.

Ohiri, A.C. and A.O. Ano (1992) Soil and fertility management for sustainable crop production in south eastern Agricultural zone of Nigeria, In: C.O. Iwuekeet al (eds.). Technology Generation under the Unified Extension Service: progress, problem and prospects, pp $22-33$, Proceedings of the $7^{\text {th }}$ Annual Farming System Workshop, NRCRI Umudike $7^{\text {th }}-11^{\text {th }}$ December 1992.

Singer, M.J and Mum, D.N. (1996) Soils, An introduction ( $3^{\text {rd }}$ ed) Prentice Hall Inc. New Jersey, USA. 480 pp.

Steel, G.D and Torrie, J.M. (1960) Principles and procedures of statistics M.G. Grand Hill book Publication Company, New york, USA. $250 \mathrm{pp}$.

Udoh, U.M and Lekwa, G (2014) Characterization and classification of selected soils in EtimEkpo LGA, Akwalbom state, Nigeria, In: S.O. Ojeniyi et al (eds) Nigerian Agricultural Transformation Agenda, pp 216-224. Proceeding of the $38^{\text {th }}$ Annual Conf. of Soil Science Society of Nigeria.Univ of Uyo, Nigeria, March 10-14, 2014.

Waterman, J.J (2000) Composition and quality of fish.Torry Research Station, Edinburgh, Uk. 250 pp.

Cite this Article: Chikere-Njoku C and Njoku DC (2017). Effect of Soil Nutrient Status on Carcass Quality of PondRaised Tilapia, Oreochromis niloticus (Linnaeus, 1758). Greener Journal of Soil Science and Plant Nutrition, 4(2):014-021, http://doi.org/10.15580/GJSSPN.2017.2.071217081 